\title{
Effects of fat supplementation in early lactation dairy cows
}

\author{
T. Kokkonen ${ }^{1,6}$, J. Taponen ${ }^{2}$, M. Tuori' ${ }^{1}$, S. Lohenoja ${ }^{1}$, M. Kulcsar ${ }^{3}$, \\ C. Delavaud ${ }^{4}$, Y. Chilliard $^{4}$ and A.T. Tesfa ${ }^{5}$
}

${ }^{1}$ Department of Animal Science, University of Helsinki, P.O. Box 28, 00014, Finland ${ }^{2}$ Department of Clinical Veterinary Medicine, University of Helsinki

Pohjoinen pikatie 800, 04920 Saarentaus, Finland,

${ }^{3}$ Faculty of Veterinary Science, Szent István University

P.O. Box 2, H-1400 Budapest, Hungary

${ }^{4}$ Herbivore Research Unit, INRA

Theix-63122 St-Genes Champanelle, France

${ }^{5}$ National Veterinary and Food Research Institute (EELA)

P.O. Box 45, 00581 Helsinki, Finland

\begin{abstract}
Twenty-four cows were fed with 0 (NF), 3.5 (MF) or 7 (HF) \% of calcium salts of palm fatty acids in the concentrate for 8 weeks after calving. The increase of total DMI in group MF tended to be slower than in the other groups during lactation weeks 1 to 4 . Fat supplementation increased milk fat content linearly during lactation weeks 1 to 4 . Liveweight and fat depth changes and concentration of plasma NEFA suggest that tissue mobilization was greater in MF than in other groups. Treatment did not significantly affect plasma hormone concentrations.
\end{abstract}

KEY WORDS: dairy cow, energy intake, milk production, tissue mobilization

\section{INTRODUCTION}

Fat supplementation of early lactation diets is an attractive alternative to diminish the gap between energy intake and the demand of high milk yield. Energy density of fat is high and long chain fatty acids are used efficiently for milk fat synthesis. Large amounts of fat may, however, have a negative impact on microbial fibre digestion in the rumen and reduce feed intake. Feeding calcium salts of fatty acids alleviates this problem (Coppock and Wilks, 1991). Another potential drawback of fat supplementation can be, paradoxically, increased lipid mobilization from adipose tissue, which is possibly facilitated by decreased blood insulin or merely a consequence of increased milk yield (Chilliard, 1993; Staples et al., 1998).

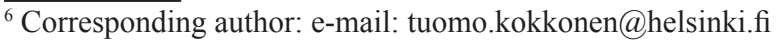




\section{MATERIAL AND METHODS}

In a randomised complete block design 24 Ayrshire cows were divided to groups with 0 (NF), 3.5 (MF) or 7\% (HF) of calcium salts of palm fatty acids (CaPFA) in concentrate (Raisio Feed Ltd, Raisio, Finland). For the first 8 weeks of lactation, grass silage was fed ad libitum, and concentrate allowance was increased to $15 \mathrm{~kg} / \mathrm{d}$ within 20 days. A digestibility experiment was conducted with 12 cows, using acid-insoluble ash (AIA) as an internal marker. Metabolizable energy (ME) content of the silage was $11.0 \mathrm{MJ} / \mathrm{kg} \mathrm{DM}$, and ME contents of the concentrates were 12.6, 13.1 and $13.6 \mathrm{MJ} / \mathrm{kg} \mathrm{DM}$ for NF, MF and HF.

Milk yield and feed intake were recorded daily. Milk samples for composition analyses were taken at 1, 2, 4, 6 and 8 wk after parturition. Liveweights (LW) were recorded daily during the week of calving, and at 2, 4, 6 and 8 wk after calving. Ultrasonic measurements of fat depth (FD) were made at calving day, and 4 and 8 weeks after calving. Blood samples were taken from superficial epigastric (mammary) vein at $1,3,5,7,14,21,28$ and $56 \mathrm{~d}$ after calving and from coccygeal (tail) vessel 5 and $28 \mathrm{~d}$ after calving.

The data for milk yield, composition, and feed intake from weeks 1 to 4 and weeks 5 to 8 , as well as blood composition data from 1 to $28 \mathrm{~d}$, were analysed as repeated measures. The statistical model included effects of treatment, block, time, and interactions of time and treatment, and time and block. The changes of LW and FD, digestibility of diet, average ME balance within the two periods and plasma NEFA at $56 \mathrm{~d}$ after calving were analyzed with the model including the fixed effect of treatment and random effect of block.

\section{RESULTS}

Although silage and total dry matter intakes (DMI) were not significantly different between treatments (Table 1), the increase of total DMI in group MF tended to be slower during lactation weeks $1-4$ (time $\mathrm{x}$ treatment $\mathrm{P}<0.10$ ) than in the other groups. Organic matter digestibility of diet did not differ between treatments. Digestibility of ether extract increased (linear effect, $\mathrm{P}<0.001$ ) and NDF digestibility decreased (linear effect, $\mathrm{P}<0.05$ ) with Ca-PFA.

Ca-PFA had no significant effect on milk yield, but the decline of milk yield during lactation weeks 5 to 8 tended to be smaller in MF and HF groups than in $\mathrm{NF}$ group (time $\mathrm{x}$ treatment $\mathrm{P}<0.10$ ). Ca-PFA increased milk fat content (linear effect, $\mathrm{P}<0.05$ ) during lactation weeks 1 to 4.

Group MF had greater LW loss (quadratic effect, $\mathrm{P}<0.05$ ) (Table 2) during lactation weeks 1 to 4 and tended to have greater decrease of FD during lactation weeks 5 to 8 than the other groups (quadratic effect, $\mathrm{P}<0.10$ ). Plasma NEFA increased linearly $(\mathrm{P}<0.01)$ with Ca-PFA 8 weeks after calving. 
Table 1. Feed intake, milk yield and diet digestibility

\begin{tabular}{|c|c|c|c|c|c|c|c|c|}
\hline \multirow{2}{*}{ Item } & \multicolumn{3}{|c|}{ Diet } & \multirow{2}{*}{ SEM } & \multicolumn{4}{|c|}{ Significance } \\
\hline & NF & MF & $\mathrm{HF}$ & & Lin. & Quadr. & time & time $\times$ treatm . \\
\hline \multicolumn{9}{|l|}{ Weeks 1 to 4} \\
\hline silage, $\mathrm{kg} \mathrm{DM} / \mathrm{d}$ & 9.7 & 9.2 & 10.0 & 0.33 & & & $* * *$ & \\
\hline total DMI, $\mathrm{kg} / \mathrm{d}$ & 19.9 & 19.4 & 20.5 & 0.46 & & & $* * *$ & o \\
\hline $\mathrm{ME}, \mathrm{MJ} / \mathrm{d}$ & 239 & 236 & 56 & 5.5 & o & & $* * *$ & o \\
\hline milk yield, $\mathrm{kg} / \mathrm{d}$ & 40.9 & 39.9 & 40.7 & 1.39 & & & $* * *$ & \\
\hline milk fat content, $\mathrm{g} / \mathrm{kg}$ & 44.2 & 47.8 & 49.2 & 1.33 & $*$ & & $* * *$ & \\
\hline \multicolumn{9}{|l|}{ Weeks 5 to 8} \\
\hline silage, $\mathrm{kg} \mathrm{DM} / \mathrm{d}$ & 9.5 & 9.3 & 9.3 & 0.49 & & & o & \\
\hline total DMI, $\mathrm{kg} / \mathrm{d}$ & 23.0 & 23.0 & 23.0 & 0.51 & & & $*$ & \\
\hline $\mathrm{ME}, \mathrm{MJ} / \mathrm{d}$ & 275 & 279 & 290 & 5.8 & & & $\mathrm{o}$ & \\
\hline milk yield, $\mathrm{kg} / \mathrm{d}$ & 46.3 & 48.2 & 48.4 & 1.33 & & & ** & o \\
\hline milk fat content, $\mathrm{g} / \mathrm{kg}$ & 40.9 & 41.0 & 41.6 & 1.55 & & & & \\
\hline \multicolumn{9}{|l|}{ Digestibility } \\
\hline organic matter, $\mathrm{g} / \mathrm{kg}$ & 725 & 719 & 710 & 8.4 & & & - & - \\
\hline ether extract, $g / \mathrm{kg}$ & 602 & 705 & 736 & 14.8 & $* * *$ & o & - & - \\
\hline $\mathrm{NDF}, \mathrm{g} / \mathrm{kg}$ & 592 & 547 & 546 & 22.1 & $*$ & & - & - \\
\hline
\end{tabular}

Table 2. Energy balance, liveweight and fat depth changes and plasma NEFA

\begin{tabular}{|c|c|c|c|c|c|c|}
\hline \multirow{2}{*}{ Item } & \multicolumn{3}{|c|}{ Diet } & \multirow{2}{*}{ SEM } & \multicolumn{2}{|c|}{ Significance } \\
\hline & NF & MF & $\mathrm{HF}$ & & Lin. & Quadr. \\
\hline \multicolumn{7}{|l|}{ Weeks 1 to 4} \\
\hline ME balance, $\mathrm{MJ} / \mathrm{d}$ & -43.8 & -54.7 & -40.2 & 12.62 & & \\
\hline liveweight change, $\mathrm{kg}$ & -9 & -38 & -16 & 9.5 & & $*$ \\
\hline fat depth change, mm & -1.8 & -2.3 & -2.2 & 0.62 & & \\
\hline NEFA (tail vein), mmol/1 ${ }^{1}$ & 0.42 & 0.53 & 0.51 & 0.063 & & \\
\hline NEFA (mammary vein), mmol// ${ }^{1}$ & 0.39 & 0.52 & 0.48 & 0.042 & & \\
\hline \multicolumn{7}{|l|}{ Weeks 5 to 8} \\
\hline ME balance, $\mathrm{MJ} / \mathrm{d}$ & -20.3 & -30.9 & -22.3 & 8.25 & & \\
\hline liveweight change, $\mathrm{kg}$ & -9 & -8 & -2 & 6.4 & & \\
\hline fat depth change, $\mathrm{mm}$ & -0.9 & -2.4 & -0.5 & 0.68 & & o \\
\hline NEFA (mammary vein, $56 \mathrm{~d}$ ), mmol/1 & 0.15 & 0.26 & 0.28 & 0.026 & $* *$ & \\
\hline
\end{tabular}

${ }^{1}$ significant time effect $(\mathrm{P}<0.001)$, no significant $(\mathrm{P}>0.10)$ time $\mathrm{x}$ treatment interaction

${ }^{\circ} \mathrm{P}<0.10, * \mathrm{P}<0.05$, ** $\mathrm{P}<0.01$

Table 3. Concentrations of plasma hormones during lactation weeks 1 to 4

\begin{tabular}{|c|c|c|c|c|c|c|c|c|}
\hline \multirow{2}{*}{ Item } & \multicolumn{3}{|c|}{ Diet } & \multirow{2}{*}{ SEM } & \multicolumn{4}{|c|}{ Significance } \\
\hline & NF & MF & $\mathrm{HF}$ & & Lin. & Quadr. & Time & time $\mathrm{x}$ treatm. \\
\hline Leptin, ng/ml & 4.75 & 4.52 & 4.36 & 0.264 & & & **** & \\
\hline Insulin, $\mu \mathrm{IU} / \mathrm{ml}$ & 14.58 & 13.54 & 12.99 & 1.350 & & & $* * *$ & \\
\hline $\mathrm{T} 3, \mathrm{nmol} / \mathrm{l}$ & 2.04 & 1.71 & 1.83 & 0.126 & & & $* * *$ & \\
\hline $\mathrm{T} 4, \mathrm{nmol} / \mathrm{l}$ & 36.37 & 31.80 & 34.56 & 2.558 & & & $* * *$ & \\
\hline IGF-1, nmol/1 & 3.78 & 3.03 & 3.22 & 0.323 & & & $* * *$ & \\
\hline
\end{tabular}

$* * * \mathrm{P}<0.001$ 
Plasma leptin, insulin, T3, T4 and IGF-1 were not significantly affected by treatment (Table 3).

\section{DISCUSSION}

A review by Allen (2000) shows that supplementation of dairy cow diets with Ca-PFA has a linear negative effect on DMI, which may be partly a problem of acceptability. In the present trial, no acceptability problems were observed. Decreased NDF digestibility suggests that supplemental fat was not completely inert in the rumen. However, the effect of Ca-PFA on feed intake was not uniform. Feed intake tended to decrease in group MF, but not in group HF.

Supplemental dietary fat increases concentration of NEFA in plasma (Chilliard, 1993). Therefore, plasma NEFA is not a very good indicator of lipid mobilization in fat supplementation studies. Nevertheless, contrary to expected linear increase, plasma NEFA (in mammary vein) tended to be highest in MF group ( $\mathrm{P}=0.11$, quadratic effect) during lactation weeks 1 to 4 . Along with greater LW and FD loss, this gives evidence for increased tissue mobilization in group MF. Reviews by Chilliard (1993) and Staples et al. (1998) suggested that dietary fat supplementation may depress plasma insulin and enhance lipolysis in adipose tissue. The present study cannot fully confirm this theory, as there were no significant differences in plasma hormone concentrations.

\section{CONCLUSIONS}

Ca-PFA increased milk fat content during lactation weeks 1 to 4 and tended to increase persistency of peak yield during lactation weeks 5 to 8. Although a tendency towards increased lipid mobilization was observed with medium CaPFA, no consistent shift towards increased catabolism was seen with Ca-PFA.

\section{REFERENCES}

Allen M.S., 2000. Effects of diet on short-term regulation of feed intake by lactating dairy cattle. J. Dairy Sci. 83, 1598-1624

Chilliard Y., 1993. Dietary fat and adipose tissue metabolism in ruminants, pigs, and rodents: A review. J. Dairy Sci. 76, 3897-3931

Coppock C.E., Wilks D.E., 1991. Supplemental fat in high-energy rations for lactating cows: effects on intake, digestion, milk yield, and composition. J. Anim. Sci. 69, 3826-3837

Staples C.R., Burke J.M., Thatcher W.W., 1998. Influence of supplemental fats on reproductive tissues and performance of lactating cows. J. Dairy Sci. 81, 856-871 